\title{
EFFICIENCY OF AMMONIA AND PHOSPHORUS REMOVAL FROM A COLOMBIAN AGROINDUSTRIAL WASTEWATER BY THE MICROALGAE CHLORELLA VULGARIS AND SCENEDESMUS DIMORPHUS
}

\author{
Luz Estela González, ${ }^{\text {* }}$ Rosa Olivia Cañizares ${ }^{\mathrm{b}} \&$ Sandra Baena ${ }^{\mathrm{a}}$ \\ ${ }^{a}$ Program of Sanitation and Environmental Biotechnology, Department of Biology, Faculty of Science, Pontificia Universidad \\ Javeriana, PO. Box 56710, Santafé de Bogotá, Colombia \\ ${ }^{b}$ Department of Biotechnology and Bioengineering, Centro de Investigaciones y de Estudios Avanzados del Instituto Politécnico \\ Nacional (CINVESTAV-IPN), PO. Box 14-740, México City, México
}

(Received 8 May 1996; revised version received 28 January 1997; accepted 19 February 1997)

\begin{abstract}
The ammonia and phosphorus removal efficiencies of the microalgae Chlorella vulgaris and Scenedesmus dimorphus, during biotreatment of secondary effluent from an agroindustrial wastewater of a dairy industry and pig farming, were evaluated. The microalgae were isolated from a wastewater stabilization pond near Santafé de Bogota, Colombia. Batch cultures were made using both species in 4-l cylindrical glass bio-reactors each containing 21 of culture. Chlorella vulgaris was also cultivated on wastewater in a tri-angular bioreactor Three 216-h experimental cycles were run for each microalga and in each bioreactor In the cylindrical bioreactor, S. dimorphus was more effi-cient in removing ammonia than C. vulgaris. However, the final efficiency of both microalgae at the end of each cycle was similar. Both microalgae removed phos-phorus from the wastewater to the same extent in a cylindrical bioreactor Using C. vulgaris, the triangular bioreactor was superior for removing ammonia and the cylindrical bioreactor was superior for removing phos-phorus. This study shows the potential of using these microalgae to reduce the environmental pollution of heavily contaminated agroindustrial waters currently disposed of untreated into the waterways and streams of tropical Colombia. (C) 1997 Elsevier Science Ltd.
\end{abstract}

Key words: Microalgae, Chlorella vulgaris, Scenedes-mus dimorphus, agroindustrial wastewater, nutrient removal, bioreactors.

\section{INTRODUCTION}

Microalgae culture systems show a versatility that allows them to participate in different processes, such as wastewater treatment, production of animal

Author to whom correspondence should be addressed. food, production of fertilizers, and production of common and fine chemicals (De la Noüe and De Pauw, 1988). The wastewater treatment by micro-algae cultures has a major advantage. It does not generate additional pollution when the biomass is harvested and it allows efficient recycling of nutrients (De la Noüe et al., 1992). The use of several microalgae and cyanobacteria in wastewater treatment is known (Calzada et al., 1991; Cañizares et al., 1994; De la Noüe et al., 1993; De la Noüe and Proulx, 1988; Serodes et al., 1986; Oswald, 1988).

Our aims were: to find microalgal species with a high efficiency of ammonia and phosphorus removal, and to compare the efficiency of the removal in two bioreactor types, cylindrical and triangular. We studied the potential of two Chlorophyceae: Chlor-ella vulgaris and Scenedesmus dimorphus. The importance of Chlorophyceae and the above micro-algae for nutrient removal is known (Cañizares and Casas, 1991; Chevalier and De la Noüe, 1985; Lav-oie and De la Noüe, 1985; Serodes et al., 1991), but not for the type of wastewater used in this study.

\section{METHODS}

\section{Microalgae}

Wild strains of Chlorella vulgaris Bejerinck and Scenedesmus dimorphus (Turp.) Kütz were isolated from a secondary effluent of a wastewater treatment stabilization pond. They were identified by micro-scopic observation according to the descriptions of Chlorophyceae in the literature. The characteristics of the wastewater in the pond are given in Table 1.

\section{Culture media}

Two sterile synthetic media were used to mantain the cultures. The medium for Chlorella vulgaris con-tained (g/1): $\mathrm{KNO}_{3}, 25 ; \mathrm{MgSO}_{4} .7 \mathrm{H}_{2} \mathrm{O}, 10 ; \mathrm{KH}_{2} \mathrm{PO}_{4}$, 
Table 1. Characteristics of the agroindustrial wastewater in a secondary treatment aerobic stabilization pond

\begin{tabular}{ll}
\hline Parameter & Mean value \\
\hline $\mathrm{pH}$ & 7.4 \\
Temperature & $19.5^{\circ} \mathrm{C}$ \\
Conductivity & $1.6 \mathrm{mS} / \mathrm{cm}$ \\
Total dissolved & $819.5 \mathrm{mg} / \mathrm{l}$ \\
$\quad$ solids & \\
Nitrates & $1.9 \mathrm{mg} / \mathrm{l}$ \\
Nitrites & 0 \\
Ammonia & $36.3 \mathrm{mg} / \mathrm{l}$ \\
Total phosphorus & $111.8 \mathrm{mg} / \mathrm{l}$ \\
Chlorides & $589.9 \mathrm{mg} / \mathrm{l}$. \\
Alkalinity & $477.2 \mathrm{mg} / \mathrm{l}$ \\
Chemical oxygen & $282.9 \mathrm{mg} / \mathrm{l}$ \\
$\quad$ demand (COD) & \\
Total suspended & $111.2 \mathrm{mg} / \mathrm{l}$ \\
$\quad$ solids (TSS) & $2465 \mathrm{cfu} / \mathrm{ml}$ \\
Fecal coliforms & $2815 \mathrm{cfu} / \mathrm{ml}$ \\
Total coliforms &
\end{tabular}

Note: The solid residues came mainly from a dairy industry, with a small quantity from pig farming. The water had high levels of fats and proteins (quantities not determined in this study). No heavy metals or industrial toxic materials were present in the wastewater (Valder-rama, 1995).

4; $\mathrm{K}_{2} \mathrm{HPO}_{4}, 1 ; \mathrm{FeSO}_{4} .7 \mathrm{H}_{2} \mathrm{O}, 1$; Micronutrients $(\mu \mathrm{g} / 1) \mathrm{H}_{3} \mathrm{BO}_{3}$, 2.86; $\mathrm{MnCl} 2.4 \mathrm{H}_{2} \mathrm{O}, 1.81 ; \mathrm{ZnSO}_{4} .7 \mathrm{H}_{2} \mathrm{O}, 0.11 ; \mathrm{CuSO}_{4} .5 \mathrm{H}_{2} \mathrm{O}$, 0.09; $\mathrm{NaMoO}_{4}, 0.021$. Bold's Basal medium used for Scenedesmus dimorphus contained (g/1): $\mathrm{NaNO}_{3}, \quad 10$; $\mathrm{CaCl}_{2} .2 \mathrm{H}_{2} \mathrm{O}, 1 ; \mathrm{MgSO}_{4} .7 \mathrm{H}_{2} \mathrm{O}, 3 ; \mathrm{K}_{2} \mathrm{HPO}_{4}, 3 ; \mathrm{KH}_{2} \mathrm{PO}_{4}, 7$; $\mathrm{NaCl}, \quad 1 ;(\mathrm{pg} / \mathrm{l}) \quad \mathrm{Na}_{2} \mathrm{EDTA}, 50 ; \mathrm{FeSO}_{4} .7 \mathrm{H}_{2} \mathrm{O}, 4.98 ; \mathrm{H}_{3} \mathrm{BO}_{3}$, 11.42; $\mathrm{ZnSO}_{4} .7 \mathrm{H}_{2} \mathrm{O}, 8.82 ; \mathrm{MnCl}_{2} .4 \mathrm{H}_{2} \mathrm{O}, 1.44 ; \mathrm{MoNO}_{3}, 0.71$; $\mathrm{CuSO}_{4} .5 \mathrm{H}_{2} \mathrm{O}, \quad 1.57 ; \quad \mathrm{Ca}\left(\mathrm{NO}_{3}\right)_{2} .6 \mathrm{H}_{2} \mathrm{O}, 0.49$ (Bischoff and Bold, 1963). To eliminate bacteria and protozoa, the wastewater was filtered using a S and S 595 paper filter (0.45 $\mu \mathrm{m}), 185 \mathrm{~mm}$ in diameter (Schleicher and Schuell, Germany) and sterilized by autoclaving for $20 \mathrm{~min}$. A 1:1 dilution of the waste-water with fresh water was necessary to reduce turbidity. The diluted wastewater was used throughout this study. The percentages of ammonia and phosphorus removal were calculated from the diluted cultures.

\section{Incubation}

To determine the nitrogen and phosphorus removal from wastewater by the microalgae, batch cultures were carried out in two types of bioreactors: a 41 cylindrical glass (working volume of 21) and a 50-1 triangular acrylic (30 1 working volume). The triangular bioreactor had dimensions of 60x70x33 cm (W/L/H). At the bottom tip, it had an aeration system composed of a silicone tubing with holes connected to ambient air supply. The microalgae inoculation volume (suspended in microalgae growth media) in each bioreactor was $10 \%(\mathrm{v} / \mathrm{v})$, with an initial concentration of approx. $2 \times 10^{6}$ cells $/ \mathrm{ml}$. All the cultures were incubated at ambient temperature $\left(20 \pm 2^{\circ} \mathrm{C}\right)$ under continuous fluorescent illumination ( $60 \mu \mathrm{mole} / \mathrm{m}^{2} / \mathrm{s}$ ) and bubble-aerated by a commercial aquarium pump.

\section{Analytical determinations}

Ammonia and phosphorus removal were followed by analyzing 45-ml samples taken every $24 \mathrm{~h}$. The first determination was made $144 \mathrm{~h}$ after beginning the culture. Each sample was centrifuged for $15 \mathrm{~min}$ at 1800 $\mathrm{x} g$ to eliminate the algae. Ammonia nitrogen, nitrates and total phosphorus were determined according to standard methods (AWWA-APHA-WPCF, 1990).

\section{Experimental design and statistical analysis}

Every experiment was composed of three independent but otherwise similar cycles. Each cycle lasted $216 \mathrm{~h}$ for each microalga in each bioreactor type. Samples for analysis were taken in triplicate for every determination. Results of the three cycles were combined and used for statistical analysis. Statistical analysis was done by One-way Analysis of Variance (ANOVA) at $P \leq 0.05$. Data were converted to arcsin before analysis.

\section{RESULTS AND DISCUSSION}

As a result of the nature of the wastewater used, variations in nutrient removal probably can be attributed to the impossibility of having similar initial nutrient concentrations for each cycle. Nevertheless, as noted by Cañizares et al. (1994), this variety of concentrations permitted the establishment of removal efficiency percentages.

Scenedesmus dimorphus always removed signifycantly more $\mathrm{NH}_{3}$ from the wastewater than $C$. vulgaris in the 41 cylindrical bioreactor. However, at the end of each cycle (after $216 \mathrm{~h}$ ) the percentage removed was the same (Fig. 1). In C. vulgaris cultures, the nitrate levels in the wastewater increased from 5 to $45 \mathrm{mg} / 1$ after $144 \mathrm{~h}$ and stayed at this level thereafter. This phenomenon did not occur with $S$. dimorphus (data not presented). Phosphorus removal efficiencies obtained by the two microalgae in a 41 bioreactor were statistically similar. The removal ranged from $20 \%$ after $144 \mathrm{~h}$ to $55 \%$ after $216 \mathrm{~h}$ (data not shown). Our results showed lower efficiencies of phosphorus removal by $C$. vulgaris and $S$. dimorphus than those reported by Lavoie and De la Noüe (1985) for other microalgae, such as the $75 \%$ for $S$. obliquus and $71-90 \%$ for Phormidium (De la Noüe and Proulx, 1988).

The efficiencies of C. vulgaris removal of ammonia and phosphorus were compared in cylindrical vs triangular bioreactors. In the triangular bioreactor, C. vulgaris removed more $\mathrm{NH}_{3}$ than in the cylindrical bioreactor. After $216 \mathrm{~h}$ of incubation, the efficiency removal was equal [Fig. 2(a)]. How- 


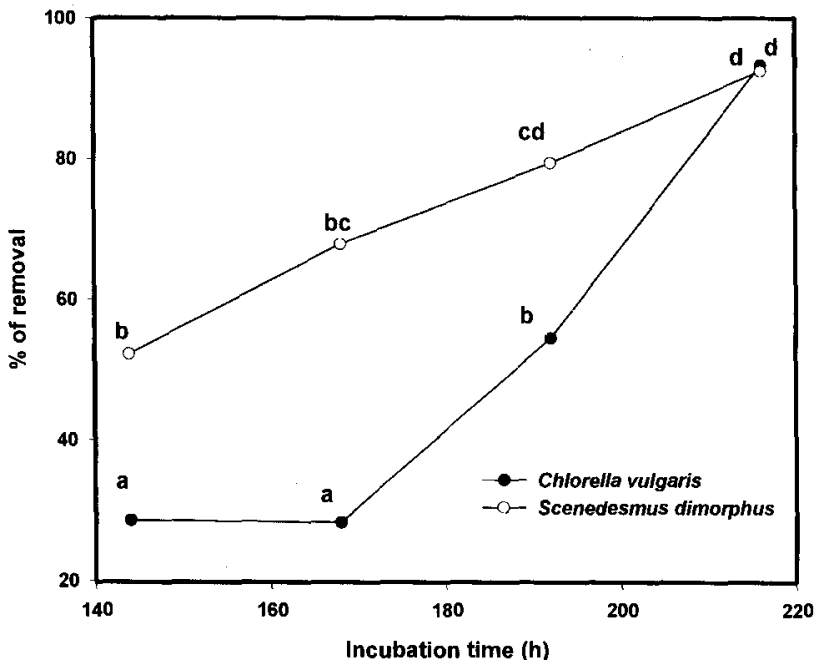

Fig. 1. Percentage of removal of $\mathrm{NH}_{3}$ from agroindustrial wastewater by $C$. vulgaris and $S$. dimorphus. Points denoted by a different letter differ significantly at $P \leq 0.05$ in one-way ANOVA.

ever, the cylindrical bioreactor was more efficient in removing $\mathrm{PO}_{4}{ }^{3-}$ than the triangular bioreactor. There, no removal of $\mathrm{PO}_{4}{ }^{3-}$ occurred [Fig. 2(b)].

The depletion of ammonia and increase in nitrates in the microalgae wastewater culture cannot be exclusively attributed to nitrogen conversion. Other mechanisms capable of eliminating ammonia ae nonbiological, such as air-stripping, absorption and sedimentation. In intensively-aerated microalgal syste-ms, like ours, the air-stripping mechanism seems to be the most important. In addition, microalgal photosynthetic activity in all culture systems 16 raised the temperature to $27-28^{\circ} \mathrm{C}$ and the $\mathrm{pH}$ to 9 , thus improving the airstripping phenomena (Talbot and De la Noüe, 1993).

The removal efficiency of ammonia by $S$. dimorphus in our study was higher than that documented for $S$. quadricauda by Chevalier and De la Noüe (1985), who reported a removal efficiency of only $23.31 \%$. However, the results we obtained with $C$. vulgaris and $S$. dimorphus are similar to Phormidium bonheri efficiency (95\%) [De la Noüe and Proulx, 1988].

There are two major ways to emove phosphorus from wastewater: (i) direct cellular absorption under aerobic conditions, and (ii) sedimentation to anoxic conditions. Phosphorus removal in our, study under aerated conditions can be explained by its interaction with the nitrogen in the water. Because nitrogen is the limiting nutrient factor in the medium, the phosphorus concentration will still be high even after ammonia exhaustion. This leads to a saturation in the phosphorus cellular absorption mechanisms (Chevalier and De la Noüe, 1985). In our study, in spite of the high oxygenation rate, the absence of a sedimentation zone in the bioreactors prevented phosphorus chelate precipitation. In con- trast, Proulx et al. (1994) determined higher phosphorus removal efficiencies $(57 \%)$ than ours, in a triangular bioreactor during Phormidium bonheri cultivation.

In tropical countries like Colombia (having an excess of freshwater caused by heavy rainfall, over $10,000 \mathrm{~mm}$ annually, in some regions), agricultural reuses of the treated wastewaters are unlikely to occur as there is no shortage of irrigation water in the country. However, disposal of less contaminated wastewater will have a major benefit for environmental pollution control. The current disposal method nationwide is a direct disposal of untreated wastewater into the waterways and streams.

In conclusion, the two microalgae wastewater treatment systems present a good option of biological tertiary treatment of agroindustrial wastewater. Both species showed a fairly high ammonia-removal efficiency, comparable to those obtained in other studies with cyanobacteria like Phormidium and Spirulina, and a moderate phosphate removal.
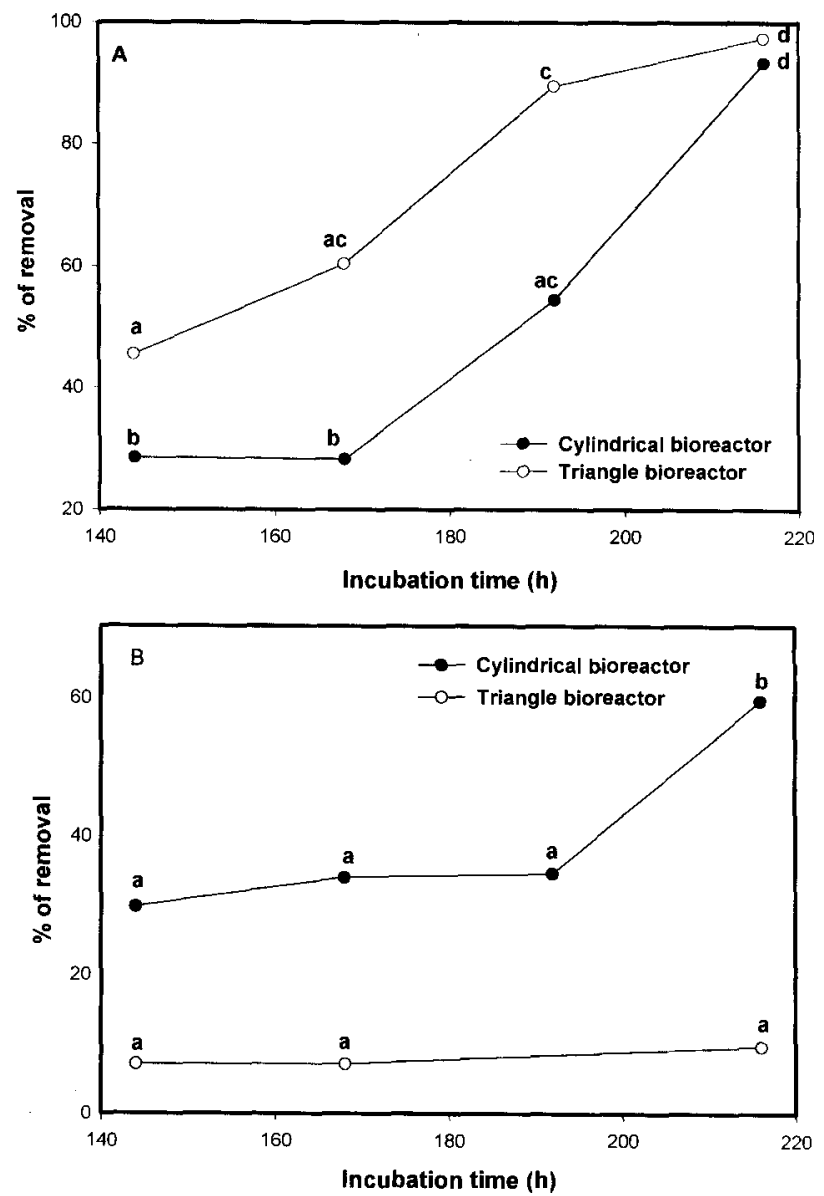

Fig. 2. Comparison of removal of ammonia (A) and phos-phorus (B) by C. vulgaris growing in agroindustrial wastewater in cylindrical and triangular bioreactor. Points denoted by a different letter, in each sub-figure, differ significantly at $P \leq 0.05$ in one-way ANOVA. 


\section{ACKNOWLEDGEMENTS}

We thank $\mathrm{Mr}$ Angel Carrillo from The Center for Biological Research of the Northwest, Mexico, for his help with statistical analysis and drawings and Dr Ellis Glazier for English editing. This project was supported by Instituto Colombiano para el Desarrollo de la Ciencia y la Tecnologia Francisco José de Caldas' COLCIENCAS, Colombia.

\section{REFERENCES}

AWWA-APHA-WPCF (1990). Standard Methods for the Examination of Water and Wastewater. 17th edn. 1105 pp.

Bischoff, H. W. \& Bold, H. C. (1963). Phycological Studies. IV. Some Algae from Enchanted Rock and Related Algae Species. University of Texas Publications number 6318. pp. 1-95

Calzada, J. F., Zabala, J., González, J. G. \& Pineda, R. (1991). Combined biological wastewater treatment anaerobic digestion and algal growth. In Memorias Sexto Simposio Internacional sobre Digestion Anaerobia. Sao Paulo, Brasil, pp. 363-369.

Cañizares, R. O. \& Casas, C. (1991). El papel de las microalgas en el tratamiento terciario de aguas residuales. Cuadernos sobre Biotecnologia. CINVESTAV-IPN. Mexico.

Cañizares, R. O., Rivas, L., Montes, C., Dominguez, A. R., Travieso, L. \& Benitez, F. (1994). Aerated swinewastewater treatment with k-carrageenanimmobilized Spirulina maxima. Biores. Tech., 47, 89-91.

Chevalier, P. \& De la Node, J. (1985). Efficiency of immobilized hyperconcentrated algae for ammonium and orthophosphate removal from wastewaters, Biotech. Lett., 7, 395-400.

De la Node, J. \& De Pauw, N. (1988). The potential of microalgal biotechnology: A review of production and uses of microalgae. Biotech. Adv., 6, 725-770.
De la Noüe, J. \& Proulx, D. (1988). Biological tertiary treatment of urban wastewaters with chitosanimmobilized Phormidium. Appl. Microbiol. Biotechnol., 29, 292-297.

De la Noüe, J., Laliberté, G. \& Proulx, D. (1992). Algae and wastewater: J. Appl. Phycol., 4, 247-254.

De la Noüe, J., Lessard, P. \& Proulx, D. (1993). Tertiary treatment of secondarily treated urban wastewater by intensive culture of Phormidium bohneri. Environ. Technol., 15, 449-458.

Lavoie, A. \& De la Noüe, J. (1985). Hyperconcentrated cultures of Scenedesmus obliquus. A new approach for wastewater biological tertiary treatment?. Water Res., 19, 1437-1442.

Oswald, W. J. (1988). Micro-algae and wastewater treatment. In Microalgal Biotechnology, ed. M.A. Borowitzka and L. J. Borowitzka. Cambridge University Press, pp. 691-707.

Proulx, D., Lessard, P. \& De la Noüe, J. (1994). Traitement tertiaire d'un effluent domestique secondaire por culture intensive de la cyanobacterie Phormidium bohneri. Environ. Technol., 15, 449-458.

Serodes, J. B., Waligora, J. J. \& De la Noüe, J. (1986). Traitement tertiaire des eaux usees domestiques por microalgues. h Comptes-Rendous 9 symposium sur le traitement des eaux usees au Canada. 11-12 Novembre, Montreal, pp. 237-249.

Serodes, J. B., Walsh, E., Goulet, O., De la Node, J. \& Lescelleur, C. (1991). Tertiary treatment of municipal wastewater using bioflocculating microalgae. Can. J. Civ. Engng, 18, 940-944.

Talbot, P. \& De la Noüe, J. (1993). Tertiary treatment of wastewater with Phormidium bonheri (Schmidle) under various light and temperature conditions. Water Res., 27, 153-159.

Valderrama, L. T. (1995). Utilización de Eichhornia crassipes Mart. (Solms), Typha angustifolia y Limnobium laevigatum (H\&B ex Wild) Heine como alternativa para mejorar el sistema de tratamiento de aguas residuales de ALPINA S.A. Tesis de Grado. Departamento de Biología, Pontificia Universidad Javeriana. Santafé de Bogotá, Colombia, p. 196. 